\title{
COMMENT
}

\section{Comment on 'Screening and identification of mimotopes of the major shrimp allergen tropomyosin using one-bead-one compound peptide libraries'}

\author{
Árpád Furka ${ }^{1}$ \\ Cellular \& Molecular Immunology (2019) 16:522; https://doi.org/10.1038/s41423-018-0173-1
}

I'm writing to comment the article of Leung et al. entitled "Screening and identification of mimotopes of the major shrimp allergen tropomyosin using one-bead-one compound peptide libraries" appearing in this journal ${ }^{1}$. The authors describe the synthesis of peptide libraries using the split and mix method and are citing as the source of this procedure (Reference 24) the paper of Lam et al. ${ }^{2}$. This paper, however, appeared in 1991, while the split and mix method was published by Furka et al. three years earlier in $1988^{3,4}$. The priority of Furka and his colleagues in introducing the split and mix method was acknowledged in later publications even by Lam and his colleagues. In one of the articles one can read: "The split synthesis method for generating libraries of this type was first described by Furka et al., who applied this method for synthesis of equimolar peptide mixtures. This synthetic method was later used to generate iterative libraries or one-bead-one-peptide libraries" ${ }^{\prime \prime}$. In another paper the authors say this: "The synthesis of libraries with a unique compound on each solid-phase particle employs a simple principle for the generation of equimolar mixtures of peptides in solution that was first described by Furka. This principle was later applied to the construction of soluble libraries for iterative screening and to bead-based libraries screened with solid-phase-binding protocols" ${ }^{\prime \prime}$.

\section{ADDITIONAL INFORMATION}

Competing interests: The authors declare no competing interests.

Publisher's note: Springer Nature remains neutral with regard to jurisdictional claims in published maps and institutional affiliations.

\section{REFERENCES}

1. Leung, N. Y. H., Wai, C. Y. Y., Ho, M. H. K., Liu, R., Lam, K. S., Wang, J. J. \& Shu, S. A. et al. Screening and identification of mimotopes of the major shrimp allergen tropomyosin using one-bead-one compound peptide libraries. Cell Mol. Immunol. 14, 308-18 (2017).

2. Lam, K. S., Salmon, S. E., Hersh, E. M., Hruby, V. J., Kazmierski, W. M. \& Knapp, R. J. A new type of synthetic peptide library for identifying ligand-binding activity. Nature 354, 82-84 (1991).

3. Furka Á, Sebestyén F, Asgedom M, Dibó G Cornucopia of Peptides by Synthesis. In Highlights of Modern Biochemistry, Proceedings of the 14th International Congress of Biochemistry. 5:47 (VSP, Utrecht, The Netherlands, 1988).

4. Furka Á, Sebestyén F, Asgedom M, Dibó G. More Peptides by Less Labor. In Proceedings of the 10th International Symposium of Medicinal Chemistry, 288 (ACS Publications, Budapest, Hungary, 1988).

5. Lebl, M., Krchnak, V., Sepetov, N. F., Seligmann, B., Strop, P., Felder, S. \& Lam, K. S. Onebead-one-structure combinatorial libraries. Biopolym. Pept. Sci. 37, 177-98 (1995).

6. Stankova, M., Wade, S., Lam, K. S. \& Lebl, M. Synthesis of combinatorial libraries with only one representation of each structure. Pept. Res 7, 292-8 (1995). 